\title{
Estudios de laboratorio sobre la conservación de la piedra de la Catedral de Murcia (1)
}

\section{Laboratory studies for stone conservation at the Cathedral of Murcia}

R. M. ESBERT, C. M. GROSSI, L. VALDEON, J. ORDAZ, F. J. ALONSO y R. M. MARCOS Departamento de Geología Universidad de Oviedo

ESPAÑA

Fecha de recepción: 16-II-1990

\section{SUMMARY}

The results of a series of laboratory tests, carried out on the bioclastic limestone used in the construction of the Murcia cathedral, are presented in this paper in order to evaluate the efficiency of certain treatment products, that eventually could be applied to that stone for improving their state of conservation. Additionally, the behaviour under accelerated ageing tests of non treated samples and the treated ones with the different products employed -ethyl silicate, oligomeric polisiloxane and poliurethane-, is compared.

\section{INTRODUCCION}

La Catedral gótico-barroca de Murcia está emplazada en el centro de dicha ciudad por lo cual, además de estar sometida al ambiente mediterráneo, se ve afectada por la contaminación urbana.

La fábrica está construida mayoritariamente con una caliza bioclástica con elevada porosidad (aproximadamente $30 \%$ ), poco cementada, que procede de canteras de la zona de Monte Guil y Mayayo, ambas ubicadas en la formación miocénica de los alrededores de la capital (1).

En numerosos puntos del edificio, fundamentalmente en el exterior, la caliza muestra un notable deterioro, siendo la

\section{INTRODUCTION}

The Gothic-Baroque Cathedral of Murcia -SE of Spain, near the Mediterranean Sea- is placed in the city centre, and at present it is exposed to urban pollution.

The Cathedral has been largely built with a poorly cemented bioclastic Miocenic limestone, with high open porosity (about $30 \%$ ), which was quarried at Monte Guil and Mayayo, near Murcia (1).

The limestone shows a noticeable deterioration in many zones of the building, especially in the external part; the granular

(1) Este articulo corresponde, en gran parte, a la comunicación presentada al "International Symposium on the Conservation of Monuments in the Mediterranean Basin" (Bari, junio 1989), bajo el tifulo: "Studies for Stone Conservation at the Cathedral of Murcia (Spain)". 
desagregación granular uno de los procesos de alteración más generalizados.

A la vista de todo ello, las intervenciones encaminadas a la conservación de dicha piedra deberán contemplar, entre sus fases, las de consolidación y/o protección. Dentro de este marco es donde se encuadra esta investigación, que presenta los resultados de las experiencias realizadas on el laboratorio, aplicando a la piedra diferentes tratamientos.

Para evaluar el posible comportamiento de los productos aplicados, una vez puestos en obra, se han realizado ensayos de envejecimiento artificial acelerado, sobre muestras tratadas y no tratadas, simulando condiciones ambientales próximas -aunque extremas- a las que puedan tener lugar en el entorno del edificio.

\section{CARACTERISTICAS DEL MATERIAL PETREO}

El material empleado en la edificación de la catedral es mayoritariamente una caliza bioclástica compuesta, según los análisis de difractometría de Rayos $X$, por: calcita $(89,5 \%)$, cuarzo $(7,5 \%)$, dolomita $(1 \%)$ y accesorios (2\%).

Es una roca de color claro, variando de casi blanca a ligeramente amarilla (10 YR $8 / 2$ y $8 / 3$ ) (2), con aspecto finamente granudo y bastante uniforme.

La observación con microscopía óptica y electrónica pone de manifiesto que, además de los minerales esenciales, la roca presenta turmalina, 6xidos de hierro y micas. Su textura es detrítica, pobremente cementada (Fig. 1). El tamaño medio de grano se sitúa alrededor de $150 \mu \mathrm{m}$. Dentro de esta composición abundan los restos fósiles (algas, foraminiferos y equinodermos principalmenie), peloides y fragmentos líticos.

Se han identificado también, en algunas muestras, minerales arcillosos del grupo de las esmectitas (Fig. 2). Sin embargo, dichos minerales no se encuentran uniformemente repartidos por toda la roca.

En la Tabla ! se recogen los valores de aquellas propiedades físicas de la caliza que condicionan su comportamiento alterológico.

En la Tabla II se representan los valores de distribución de los tamaños de los poros, obtenidos mediante porosimetría de inyección de mercurio. disaggregation being one of the most generalized weathering processes.

Consequently, it seems that any intervention designed for the conservation of this stone must necessarily include, in its procedures, those of consolidation and/or protection. This paper presents the results of the laboratory experiments carried out in applying to the stone some different treatments.

For evaluating the "in situ" behaviour of the appiied products, some accelerated ageing tests on treated and non-treated samples have been performed, trying to simulate environmental conditions -although extremeclose to those existing in the vicinity of the building.

\section{CHARACTERISTICS OF THE STONE MATERIAL}

The building slone of the Cathedral of Murcia is mainly a limestone whose composition deduced from X-Ray difractometric analysis is: calcite (89.5\%), quartz (7.5\%), dolomite (1\%) and accesories (2\%).

It is a light coloured stone, varying from nearly white to light yellow (10 YR/2 and 8/3) (2), and showing a fine grained and quite uniform aspect.

Under optic and scanning electron microscopy some accesory minerals -tourmaline, iron oxides, and micas- can be observed in addition to the principal rockforming minerals. The mean grain size is about $150 \mu \mathrm{m}$. Fossil remains (mainly algae, foraminifera and equinoderms), peloids and rock fragments can be observed in the rock.

In some samples, argillaceous minerals from the smectite group can also be observed (Fig. 2), However, these minerals are not uniformly distributed throughout the rock.

In Table I, the values of some physical properties of this stone, which mainly condition its weatherability, are presented.

Table II shows the pore size distribution obtained by means of mercury injection porosimmetry. 


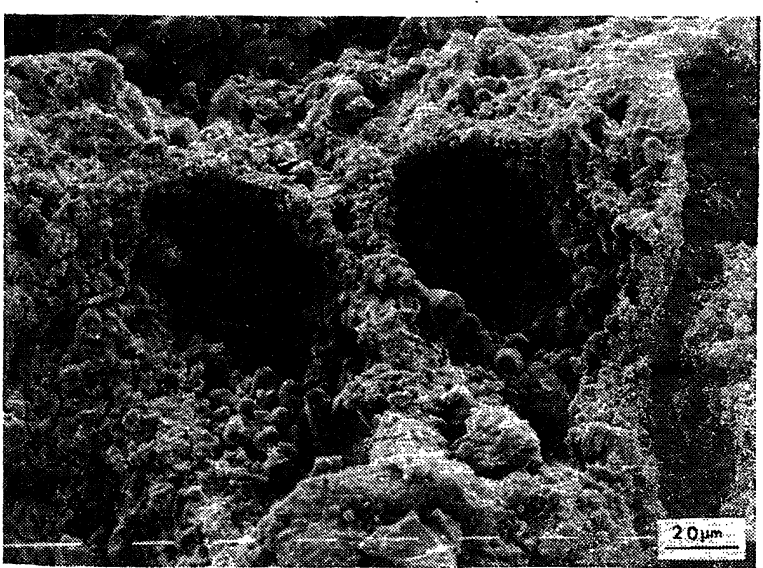

Fig. 1

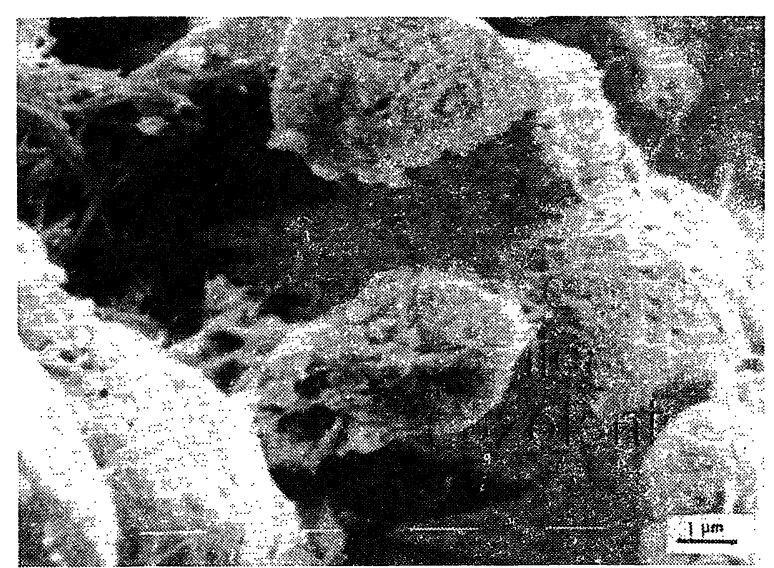

Fig. 2

Figs. 1 y 2.-Detalles de la textura de la roca. En la Fig. 1, se observan los cristales de calcita poco cohesionados, con abundancia de espacios vacios (intercristalinos y móldicos). En la Fig. 2 se aprecian, al M.E.B., las arcillas tipo esmectita recubriendo los granos. Piedra de Murcia.

Figs. 1 and 2-Details of the rock texture. Fig. 1 shows the calcite crystals with low cohesion and many voids (intercrystaline and mouldic pores). Fig. 2 shows clays of smectite type coating the grains. Murcia stone.

TABLA | (TABLE I)

Propiedades fisicas (Physical properties)

\begin{tabular}{|c|c|c|c|c|}
\hline$\rho_{\mathrm{g}} \mathrm{kg} / \mathrm{m}^{3}$ & $n_{\mathrm{o}}(\%)$ & C.I. (\%) & Ws (\%) & C.A. $\mathrm{g} / \mathrm{cm}^{2} \cdot \mathrm{s}^{1 / 2}$ \\
\hline 1,813 & 30 & 11,7 & 18 & $1,73 \cdot 10^{-2}$ \\
\hline
\end{tabular}

P. - Densidad aparente (Bulk density) (3).

$\mathrm{n}_{\mathrm{o}}$.-Porosidad abierta (Open porosity) (3).

Ws.-Contenido en humedad de saturación (agua absorbida en inmersión por saturación) [Water saturation contents (absorbed water under forced saturation)] (3).

C.I.-Capacidad de imbibición (agua absorbida en inmersión libre) [Imbibition capacity (absorbed water under free inmersion)] (4).

C.A.-Coeficiente de capilaridad (Capillarity coefficient) (5).

TABLA \| (TABLE $\|)$

Distribucion de tamaños de poro (Pore size distribution)

\begin{tabular}{|c|c|c|c|}
\hline & $n_{\circ}(\%)$ & $\begin{array}{c}\text { macroporosidad (\%) } \\
\text { (macroporosity \%) }\end{array}$ & $\begin{array}{c}\text { microporosidad (\%) } \\
\text { (microporosity \%) }\end{array}$ \\
\hline $\begin{array}{c}\text { Caliza Cat. M. } \\
\text { (Murcia limestone) }\end{array}$ & 30 & 16 & 14 \\
\hline
\end{tabular}

$\mathrm{n}_{\mathrm{o}}$ - - Porosidad abierta (open porosity).

Macroporosidad (Macroporosity).-Poros con radio de acceso > 7,5 $\mu \mathrm{m}$ (pore-thorat radius > $7.5 \mu \mathrm{m}$ ).

Microporosidad (Microporosity).-Poros con radio de acceso $<7,5 \mu \mathrm{m}$ (pore-throat radius $<7.5 \mu \mathrm{m}$ ).

Los valores obtenidos en la Tabla I ponen de manifiesto que se trata de una caliza de elevada. porosidad abierta $(30 \%)$, baja densidad $(1.813$ $\mathrm{kg} / \mathrm{m}^{3}$ ), una elevada capacidad de imbibición en agua $(11,7 \%)$ y muy alta succión capilar $\left(1,73.10^{-2} \mathrm{~g} / \mathrm{cm}^{2} \mathrm{~s}^{1 / 2}\right)$.
According to the values in Table 1 , the Murcia limestone is a stone with a high open porosity (30\%), low density $(1,813$ $\left.\mathrm{kg} / \mathrm{m}^{3}\right)$, high water imbibition capacity (11.7\%) and very high capillary suction $\left(1.73 .10^{-2} \mathrm{~g} / \mathrm{cm}^{2} \mathrm{~s}^{1 / 2}\right)$. 
En cuanto a la configuración del sistema poroso, y según se desprende de la Tabla II, la porosidad comunicada pude atribuirse, en igual proporción, a macroporos y microporos.

Las Figs. 3, 4 y 5 muestran la cinética de absorción, desorción y succión capilar de agua, por parte de la caliza bioclástica de Murcia. De su observación se deduce que en todos los casos la captación y pérdida de agua son muy rápidas.

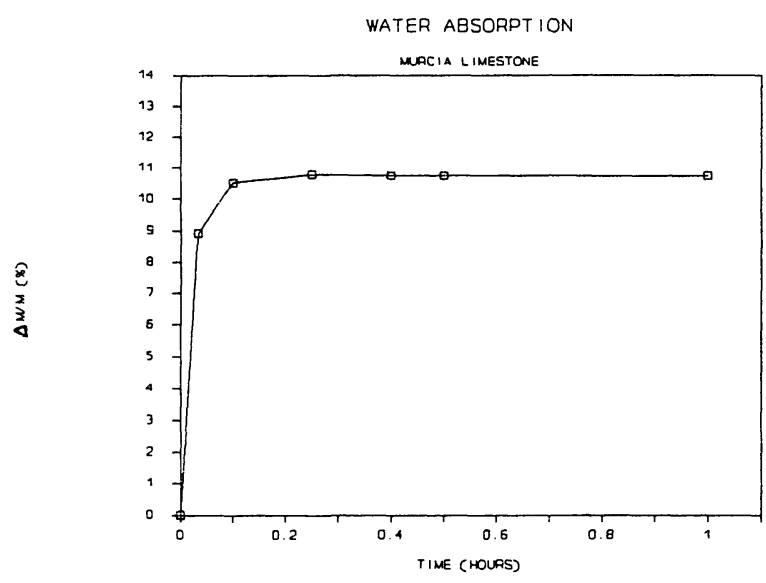

Fig. 3

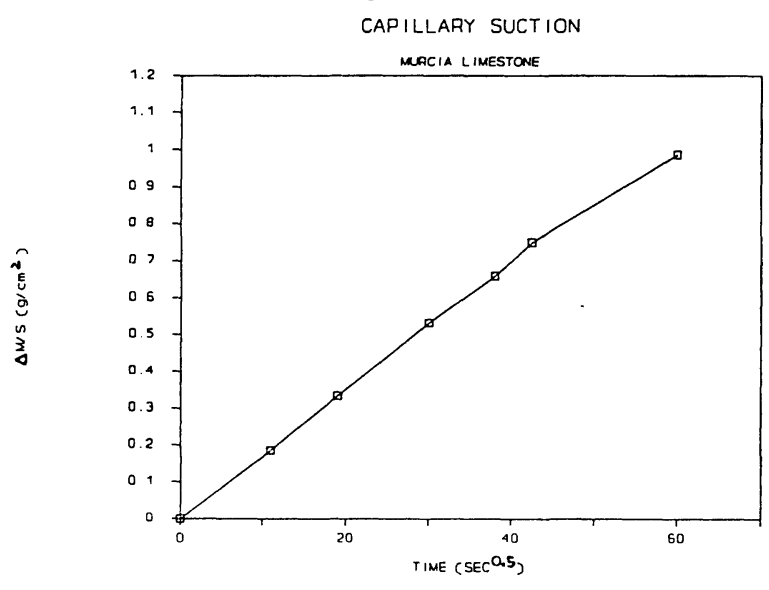

Fig. 5

\section{DETERIORO DE LA PIEDRA}

El deterioro del material pétreo es, en muchos casos y como se indicaba en la introducción, avanzado, sobre todo en determinadas zonas del exterior; hasta tal punto que, por ejemplo, la fachada gótica de los Apóstoles ha requerido recientemente una intervención. Este deterioro obedece a procesos de carácter mixto, principalmente mecánicos y físicos-químicos, no debiéndose descartar tampoco la incidencia de factores de carácter biológico.
From Table II it can be deduced that the open porosity is equally assigned to the macroporosity and to the microporosity.

In Figs. 3, 4 and 5 the water absorption, desorption and capillary suction rates of this sione are presented. Both the caption and loss of water are very fast.

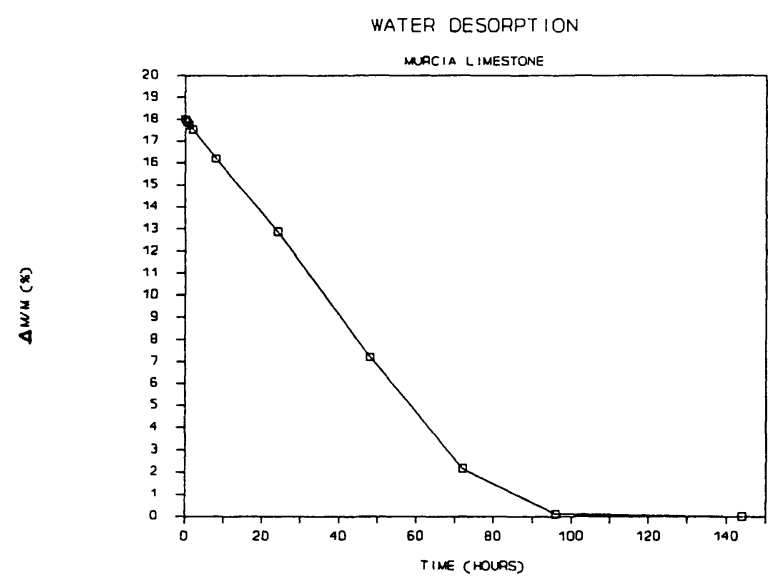

Fig. 4

Figs. 3, 4 y 5.-Absorción libre, desorción y succión capilar de agua de la piedra de la Catedral de Murcia.

Figs. 3, 4 y 5.-Water absorption, desorption and capillary suction rates of the Murcia stone.

\section{STONE DECAY}

The Murcia stone shows a high degree of deterioration, especially in several zones of the exterior of the monument; to the extent that the Gothic façade of the Apostles has required a recent intervention. This decay is due to combined processes, mainly physico-chemical and mechanical, and also possibly to the incidence of biological factors. 
Los procesos mecánicos están relacionados con las variaciones de humedad y oscilaciones térmicas, las cuales suelen generar tensiones internas en la piedra, que se traducen en la aparición de fisuras o fracturas de diverso tamaño.

En cuanto a los procesos físico-químicos, la existencia de interacciones químicas, en presencia de agua, entre ciertas sustancias exógenas, procedentes fundamentalmente de la contaminación atmosférica, y los componentes de la roca, generan principalmente descohesiones, descamaciones, desconchaduras, pátinas y costras (6).

\section{TRATAMIENTOS APLICADOS. ENSAYOS DE ENVEJECIMIENTO ARTIFICIAL ACELERADO}

Dado el tipo y grado de deterioro que presenta la piedra de la Catedral, asi como las condiciones ambientales de la ciudad de Murcia, con una humedad relativa media del $57 \%$, se han seleccionado, para la experimentación en el laboratorio, dos tipos de tratamientos: uno con efecto consolidante $\theta$ hidrofugante (silicato de etilo y polisiloxano oligomérico), y otro sólo con efecto hidrofugante (poliuretano).

Los dos productos del primer tratamiento son Tegovakon $V$ y Tegosivin HL-100, respectivamente (ambos de la firma comercial Th. Goldchsmidt); el segundo es el Phoba 10 (de Hispano-Química S.A.). La aplicación ha sido en ambos casos por inmersión total, durante cinco días, utilizando probetas cúbicas de $5 \mathrm{~cm}$ de arista (7).

Se han evaluado, tras el tratamiento, la ganancia de peso de las piedras tratadas, las variaciones de color, así como las diferencias de comportamiento entre las piedras sin tratar y tratadas, a lo largo de ciclos de humedad-sequedad, cristalización de sales, exposición a la radiación ultravioleta y calentamiento-enfriamiento. Para cada ensayo se utilizaron cinco probetas.

En la Tabla III se aprecia la ganancia de peso experimentada con uno y otro tratamiento. La Tabla IV recoge la medida del color según la escala Munsell (2), antes y después de los tratamientos.
The mechanical processes are related to humidity variations and thermal fluctuations, which develop internal stresses in the stone, and consequently induce fissures or fractures variable in size.

As far as the physico-chemical processes is concerned, the chemical interactions in presence of water among certain exogenous substances, mainly proceeding from the atmospheric pollution and the rock components, cause decohesion, desquamation, flaking, patinas and crusts (6).

\section{APPLIED TREATMENTS AND ACCELERATED AGEING TESTS}

According to the type and degree of deterioration shown by the stones of the cathedral, as well as the environmental conditions of Murcia city, with a mean relative humidity of $57 \%$, two different treatments have been experimented in the laboratory: One of the treatments consists of a consolidant and water-repelent effect (ethyl silicate and oligomeric polysiloxane); the other is only a water-repelent (poliurethane).

The two components in the first treatment are Tegovakon $V$ and Tegosivin HL-100, respectively (both from Th. Goldschmidt), in the second one it is Phoba 10 (from Hispano-Quimica, S.A.). In both cases they were applied to cubic specimens, $5 \mathrm{~cm}$. edge, by total immersion during five days (7).

The weight increase and colour variations in the treated stones, as well as some other differences between the treated and the non-treated stones have been evaluated after the wetting-drying, salt crystallization, ultraviolet light exposure, and heating-cooling cycles. Five specimens were used in each test.

Table III shows the weight increase experimented by the specimens of the Murcia stone after the treatments applied. Table IV shows the colour variations according to Munsell's chart (2) before and after the treatments. 
TABLA III (TABLE III)

Tratamientos: incremento de peso (Treatments: weight increase)

\begin{tabular}{|c|c|c|}
\hline Tratamiento (Treatment) & Ganancia peso (\%) (Weight increase \%) & Desv. típica (Stand. dev.) \\
\hline TV y HL-100 (TV and HL-100) & 5,1 & 0.4 \\
Phoba 10 & 0,3 & 0,1 \\
\hline
\end{tabular}

TABLA IV (TABLE IV)

Tratamientos: variación del color (Treatments: coiour variation)

\begin{tabular}{|c|c|}
\hline Tratamiento (Treatment) & Color (escala Munsell) [Coiour (Munsell chart)] \\
\hline No tratada (Non treated) & $\begin{array}{l}\text { Entre } 10 \text { YR } 8 / 2 \text { (blanco) y } 8 / 3 \text { (pardo muy pálido) [Between 10 YR } 8 / 2 \\
\text { (white) and } 8 / 3 \text { (Very pale brown)] } \\
10 \text { YR } 8 / 3\end{array}$ \\
TV y HL-100 (TV and HL-100) & $\begin{array}{c}\text { Entre } 10 \text { YR } 8 / 2 \text { y } 8 / 3 \text { (Between } 10 \text { YR } 8 / 2 \text { and } 8 / 3 \text { ) } \\
\text { Phoba } 10\end{array}$ \\
\hline
\end{tabular}

\section{Ciclos de humedad-sequedad}

Un ciclo completo (24 horas) ha constado de las siguientes fases:

inmersión: inmersión total a temperatura ambiente durante 16 horas.

Secado: En un horno con ventilación forzada a $60^{\circ} \mathrm{C}$ durante unas 6 horas.

Enfriamiento: a temperatura ambiente durante las horas restantes (8).

Se han realizado 15 ciclos.

\section{Ciclos de cristalización de sales}

Se ha utilizado una solución acuosa de sulfato sódico decahidratado a) $14 \%$. La solución se ha renovado cada 2 ó 3 ciclos.

Un ciclo completo ha constado de las siguientes fases:

Inmersión: 4 horas.

Secado: 14 horas, a $60^{\circ} \mathrm{C}$ en un horno con ventilación forzosa.

Enfriamiento: 6 horas, a temperatura ambiente.

\section{Wetting-drying cycles}

One complete cycle (24 hours) includes the following steps:

Immersion: Total immersion at room temperature during 16 hours.

Drying: in an oven with forced ventilation at $60^{\circ} \mathrm{C}$ during 6 hours approximately.

Cooling: At room temperature during 2 hours (8).

15 cycles were performed.

\section{Salt crystallization cycles}

An aqueous solution of $14 \%$ decahydrated sodium sulphate has been used. The solution was renewed each two or three cycles.

One complete cycle includes the following steps:

Immersion: 4 hours.

Drying: 14 hours, at $60^{\circ} \mathrm{C}$ in an oven with forced ventilation.

Cooling: 6 hours at room temperature. 
Al final del ensayo se han lavado las muestras con agua destilada para la eliminación de sales, renovándose el agua con frecuencia (8). Se han realizado 11 ciclos.

\section{Ciclos de exposición a la luz ultravioleta}

Las condiciones del ensayo han sido:

Humedad relativa: $75 \%$.

Temperatura: $20^{\circ} \mathrm{C}$.

Distancia de las probetas a las lámparas de irradiación: $25 \mathrm{~cm}$.

Las radiaciones ultravioletas han sido producidas por cuatro lámparas germicidas Phillips TUV (15WG15T8) con una iluminación total de 320 lux (9). Se han realizado 60 ciclos de 12 de horas de exposición cada uno.

\section{Ciclos de calentamiento-enfriamiento}

Se han realizado en un horno eléctrico programable, conectado a un emisor-regulador con detección opto-electrónica. Las temperaturas han oscilado de 25 a $80^{\circ} \mathrm{C}$.

Cada ciclo ha constatado de una fase de calentamiento con subida de temperatura de 25 a $80^{\circ} \mathrm{C}$ en 30 minutos $y$ mantenimiento de esta temperatura durante 60 minutos, seguida de otra de enfriamiento, con descenso de la temperatura hasta $25^{\circ} \mathrm{C}$, en 180 minutos, manteniéndose esta temperatura durante 90 minutos. Se han realizado 60 ciclos.

\section{RESULTADOS}

La valoración de los ensayos se ha efectuado mediarite observación visual, mediciones en las pérdidas de peso y observación, al microscopio electrónico de barrido, de la superficie de las piedras tratadas.

La Tabla $V$ recoge la pérdida de peso en los ciclos de humedad-sequedad y cristalización de sales, de las piedras $\sin$ tratar y tratadas.

De la Tabla $V$ se deduce que los ciclos de humedad-sequedad prácticamente no afectan a la piedra, tal como se constata a simple vista.
At the end of the test, the samples were washed with distilled water in order to eliminate the remaining salts, renewing the water frequently (8). 11 cycles were performed.

\section{UV light exposition}

The tests conditions were: $75 \%$ relative humility and $20^{\circ} \mathrm{C}$ temperature. The UV radiations were produced by 4 germicide lamps Phillips TUV (15WG15T8) with a total illumination of 320 lux (9). The distance to the specimens from the irradiation lamps was $25 \mathrm{~cm}$. 60 cycles, each one of 12 hours of exposition, were performed.

\section{Heating-cooling cycles}

These cycles were carried out in an electric, programmable oven, conected to a regulating transmitter with opto-electronic detection. Temperatures ranged from 25 to $80^{\circ} \mathrm{C}$.

Each cycles consisted of a heating phase up to $80^{\circ} \mathrm{C}$ in 30 minutes, maintaining the maximum temperature for 60 minutes; and a cooling phase to $25^{\circ} \mathrm{C}$ in 180 minutes, and maintaining that temperature for 90 minutes. 60 cycles were performed.

\section{RESULTS}

Different procedures were applied to evaluate the effects of the ageing tests: naked-eye observations, measurement of the weight losses and examination of the surface of the treated stones under scanning electron microscopy.

Table $V$ shows the weight losses in the wetting-drying and salt crystallization tests, for the treated and the non-treated specimens.

From the data in Table $V$ it can be deduced that the wetting-drying cycles practically do not affect the stone, as it can be confirmed by simple visual observations. 
TABLA V (TABLE V)

Ensayos de envejecimiento artificial acelerado (Accelerated ageing tests)

\begin{tabular}{|c|c|c|}
\hline \multirow{2}{*}{ Tratamiento } & \multicolumn{2}{|c|}{ Pérdida de peso (\%) (Weight losses \%) } \\
\cline { 2 - 3 } & Humedad-sequedad (Wetting-drying) & Cristalización sales (Salt crystallization) \\
\hline \multirow{2}{*}{ No tratada (Non-treated) } & 0,1 & 5,5 \\
TV y HL-100 (TV and HL-100) & 0,3 & 0,4 \\
Phoba 10 & 0,06 & 0,06 \\
\hline
\end{tabular}

El ensayo de cristalización de sales deteriora sensiblemente la piedra sin tratar (Fig. 6); sin embargo las muestras tratadas permanecen al final de los ciclos prácticamente inalteradas (Figs. 7 y 8 ).

Las ligeras pérdidas de peso (0.3 y $0.4 \%)$ que experimentan las piedras tratadas con TV y HL-100 en los ensayos de humedad-sequedad y cristalización de sales podrían relacionarse con una incompleta reacción del silicato de etilo.

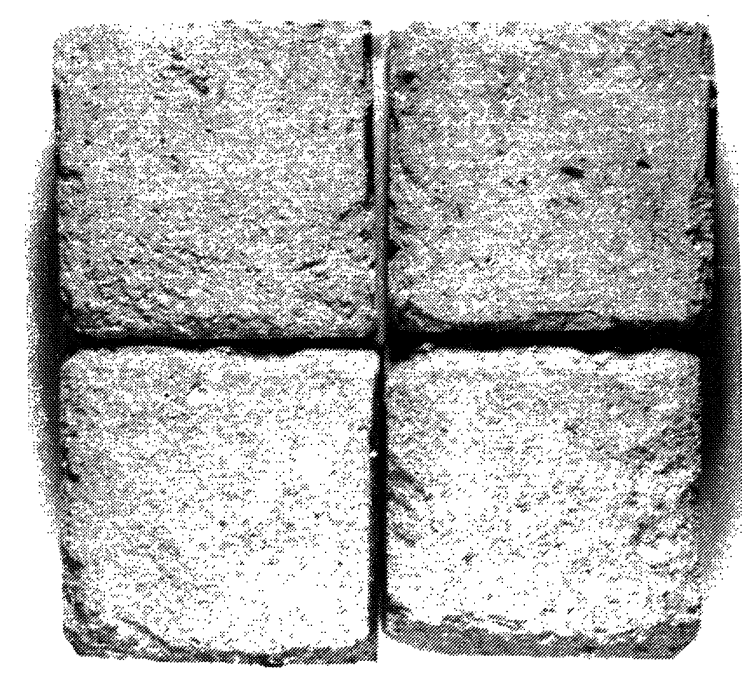

Fig. 6

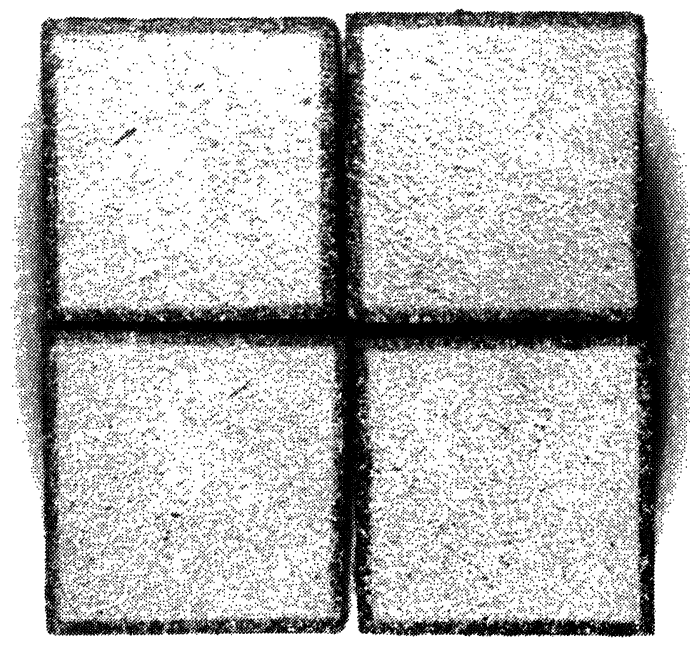

Fig. 8
The salt crystallizacion test significantly deteriorates the non-treated specimens (Fig. 6); however, the treated ones remain up to the end of the cycies practically unaltered (Figs. 7 and 8).

The scarce weight losses (0,3 and 0,4\%) experimented by the stones treated with TV and $H L-100$ in the wetting-drying and salt crystallization tests, could be related to an incomplete reaction of the ethyl silicate.

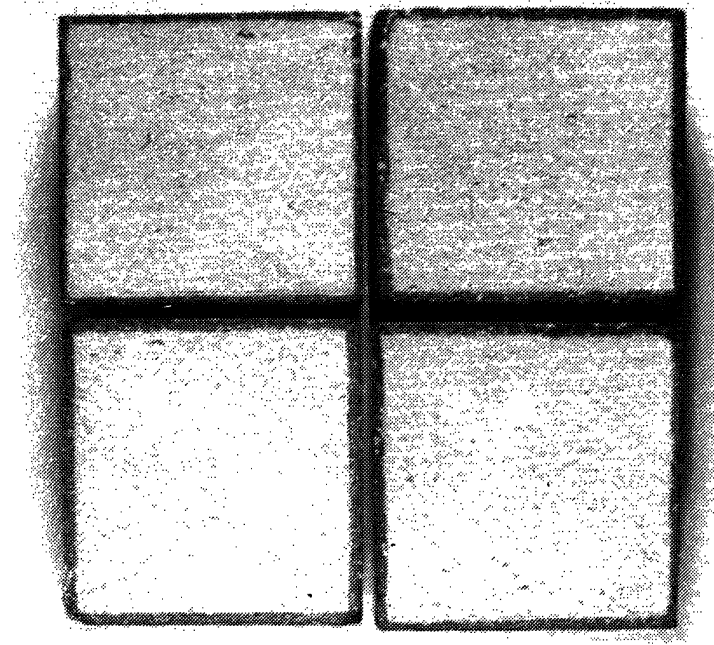

Fig. $?$

Figs. 6, 7 y 8.-Aspecto de la piedra de la Catedral de Murcia, sometida al ensayo de cristalización de sales. La Fig. 6 corresponde a muestras no tratadas; la 7 y la 8 son las piedras tratadas con TV y HL-100 y Phoba 10, respectivamente.

Figs. 6, 7 and 8.-Aspect of the Murcia stone after. the salt crystallization test, for non-treated specimens, treated with TV and HL-100, and treated with Phoba 10, respectively. 
La Figura 9 muestra la variación de peso de las piedras sin tratar y tratadas, on el ensayo de cristalización de sales. Se evidencia el distinto comportamiento entre unas y otras. Así, en las no tratadas, la pérdida es mucho mayor, siguiendo una evolución similar a la descrita por Niesel (10).

Las muestras tratadas experimentan un ligero aumento de peso a lo largo de los ciclos, debido a la pequeña acumulación de sales. La ligerísima pérdida de peso observada en el ciclo 15 (lavado), se debe a la eliminación de estas sales.

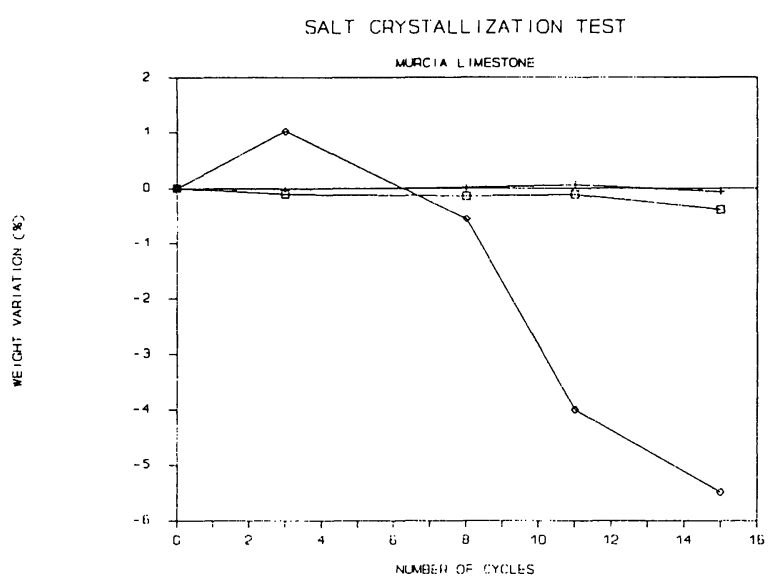

En el ensayo de exposición a la luz ultravioleta, no se han observado cambios importantes en el color de las piedras tratadas. En el caso del tratamiento con TV y HL-100 las muestras se aclaran ligeramente tendiendo el color hacia el 10 YR 8/2. En el caso del Phoba 10, el cambio es todavía menos apreciable, las muestras se aclaran ligeramente, aunque manteniéndose dentro de la tonalidad original (10 YR 8/2).

El ensayo de calentamiento-enfriamiento se ha llevado a cabo para intentar evaluar la posible microfisuración inducida en los tratamientos por las fluctuaciones térmicas. Una vez finalizados los ciclos, se han observado al microscopio electrónico de barrido (MEB) muestras de la superficie de las piedras tratadas.

Se ha visto que el tratamiento con TV y HL-100 recubre los componentes de la piedra y presenta abundantes microfisuras inherentes a su naturaleza y relacionadas con la precipitación de la sílice (Fig. 10).
Figure 9 shows the weight variation in the treated and the non treated specimens after salt crystallization tests. Their different behaviour is evident; the weight loss is very high in the non treated stones, following an evolution through the cycles similar to that described by Niesel (10).

The treated specimens evidence a light increase in weight through the cycles due to the slight accumulation of salts. The very light weight loss observed in cycle 15 (washing) is due to the elimination of those salts.

Fig. 9.- Variación de peso de la caliza de la Catedral de Murcia (sin tratar y tratada) durante el ensayo de cristalización de sales. El ciclo número 15 corresponde a la etapa de lavado.

Fig. 9.-Weight variations in the Murcia stone during the salt crystallization test, for treated and non-treated specimens. Cycle 15 corresponds to the washing phase.

There were not observed remarkable changes in colour in the UV light exposure. In the case of the treatment with TV and $H L-100$ the specimens clear up slightly, the colour tending to $10 \mathrm{YR} 8 / 2$. With Phoba 10 the change is less evident, the specimens clearing up, although remaining within the original colour (10 YR 8/2).

The heating-cooling tests were carried out for evaluating the possible cracking induced in the treatments by thermal fluctuations. After the test, the surfaces of the treated specimens were observed under scanning electron microscopy (SEM).

The treatment with TV and HL-100 covers the components of the stone and presents abundant cracks and fissures related to the precipitation of the silica-gel (Fig. 10). After the 
Parece que una vez realizados los ciclos térmicos la densidad de microfisuras aumenta.

En cuanto a las muestras tratadas con Phoba 10 (Fig. 11), el recubrimiento de la piedra por parte del tratamiento no sufre modificaciones ni a lo largo ni al final de los ciclos térmicos programados.

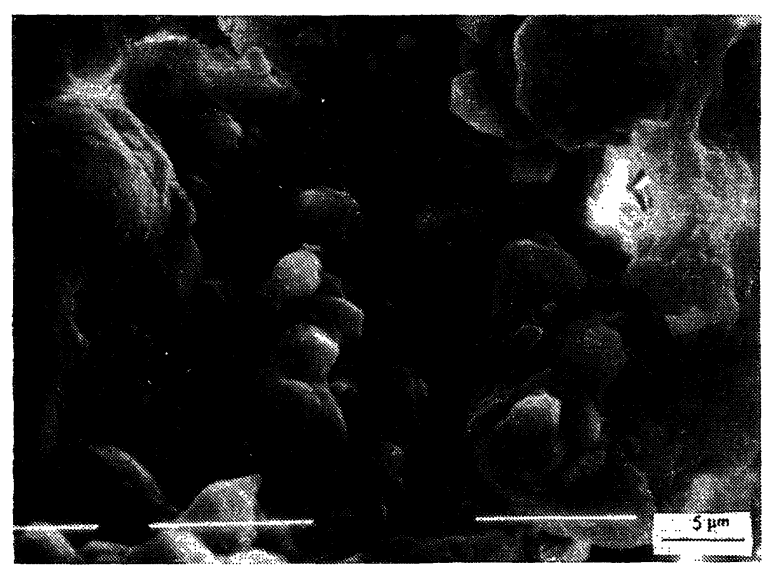

Fig. 10.-Micrografía al MEB de la piedra de la catedral de Murcia tratada con TV y HL-100.

Fig. 10.-SEM micrography of the Murcia stone after being treated with TV and HL-100.

\section{AGRADECIMIENTOS}

Los autores desean expresar su agradecimiento a la Consejería de Cultura -Servicio de Patrimonio Arquitectónico- de la Comunidad Autónoma de Murcia, para quien se realizó en 1988 un estudio titulado "Caracterización petrofísica, petroquímica, mecánica y alterológica de los materiales utilizados en la Catedral de Murcia". La presente publicación recoge algunos de los aspectos incluidos en dicho estudio.

A la "Comisión Interministerial de Ciencia y Tecnología" (CICYT), España. Proyecto N. ${ }^{2} 485 / 88$.

También agradecer a D. Alfredo Vera Boti, arquitecto, su valiosa colaboración en el transcurso del trabajo realizado para la Consejería de Murcia. heating-cooling tests the crack density seems to increase.

For the specimens treated with Phoba 10 (Fig. 11), the coating of the stone does not show modifications, neither through the cycles nor at the end of the thermal cycles performed.

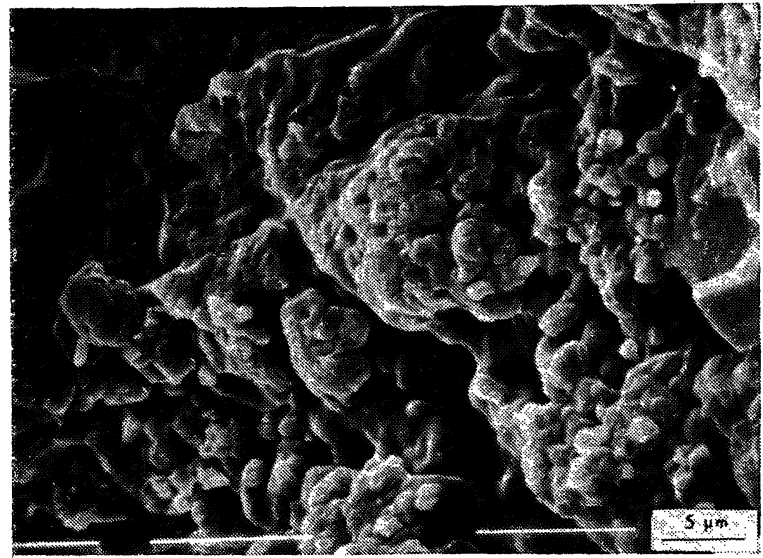

Fig. 11.-Micrografia al MEB de la piedra de la catedral de Murcia tratada con Phoba 10

Fig. 11.-SEM micrography of the Murcia stone after having been treated with Phoba 10.

\section{ACKNOWLEDGEMENTS}

The authors wish to acknowledge to the "Consejería de Cultura de la Comunidad Autónoma de Murcia" (Spain) for the financing of the research: "Petrophysical, petrochemical, mechanical and alterological characterization of the stone materials used in the Murcia cathedral" (1988). The present paper employs some aspects included in that study.

The "Comisión Interministerial de Ciencia $y$ Tecnología" (CICYT), Spain. Projeet N. ${ }^{\circ} 485 / 88$

Also thanks to Mr. Alfredo Vera Boti architect, for his valuable collaboration in the development of the research mentioned above.

\section{BIBLIOGRAFIA}

(1) I.G.M.E. (1974): Mapa geológico de España. Escala 1:50.000. Hoja n. ${ }^{9} 933$, Alcantarilla.

(2) GODDARD EN, TRASK PD, DE FORD RK, ROVE ON, SINGEWALD JT, QUERBECK RM (1979): Rock-Color-Chart. The Geological Society of America, Boulder, Co. U.S.A. 
(3) R.I.L.E.M. (1980): Essais recommandées pour l'alteration des pierres et évaluer l'efficacité des méthodes de traitement. Matériaux et Constructions, 13 (75), pp. 216-220.

(4) C.N.R.-I.C.R. (1981): Assorbimento d'acqua per immersione totale. Capacità d'imbibizione. NORMAL 7/81, Roma, $5 \mathrm{pp}$.

(5) C.N.R.-I.C.R. (1985): Assorbimento d'acqua per capillarità. Coefficiente di assorbimento capillare. NORMAL 11/85. Roma, 7 pp.

(6) ESBERT RM, GROSSI CM, ORDAZ J, ALONSO FJ, SUÁREZ DEL RÍO LM, RUIZ DE ARGANDOÑA VG, CALLEJA L Y RODRIGUEZ REY A (1988): Caracterización petrofísica, petroquímica y alterológica de los materiales utilizados en la Catedral de Murcia (Informe Primera Fase). Departamento de Geología. Universidad de Oviedo, $100 \mathrm{pp}$.

(7) LAZZARINI L, LAURENZI-TABASSO M (1986): II restauro della pietra. Dott. Antonio Milani (Edit), Padova, 320 pp.

(8) ESBERT R. M., GROSSI C., MARCOS R. M. (1987): Laboratory studies on the consolidation and protection of calcareous materials in the Cathedral of Oviedo. Part II. Materiales de Construcción, Vol. 37, n. ${ }^{2} 208$, Madrid, pp. 13-21.

(9) LAURENZI-TABASSO M., SANTAMARIA U. (1985): Consolidant and protective effects of different products on Lecce Limestone. Proc. of the Vth International Congress on Deterioration and Conservation of Stone, Lausanne, pp. 697-707.

(10) NIESEL K. (1978): L'évolution de la diminution de la masse comme basse pour l'évaluation de l'essai de cristallisation. Proc. of the International Symposium on Deterioration and Protection of Stone Monuments, Paris, $3.5,13 \mathrm{pp}$.

\section{publicaciones del ICCET/CSIC}

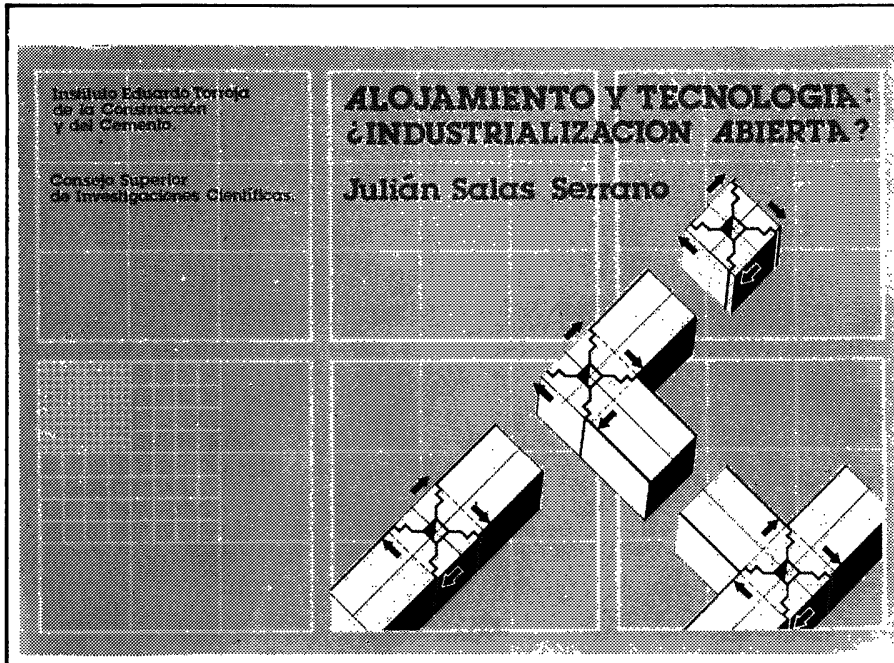

\section{ALOJAMIENTO Y TECNOLOGIA:} ¿INDUSTRIALIZACION ABIERTA?

JULIAN SALAS, ING. IND. (I.E.T.c.c.) Un volumen de 160 páginas, 109 figuras y 16 tablas. Tamaño $240 \times 168 \mathrm{~mm}$. Encuadernado en rústica. Precios: España, 1.200 ptas; extranjero, 17 \$ USA.

\section{SUMARIO:}

Prólogo Prof. G. Ciribini.

\section{Introducción}

Capítulo 1.- La industrialización en las proclamas y manifiestos de arquitectura.

Capitulo 2.-¿Réquiem por la construcción industrializada?

Capítulo 3. - Algunos conceptos básicos.

Capítulo 4.-¿Proyecto tradicional, construcción industrializada?

Capitulo 5.-Componentes.

Capitulo 6. - La coordinación dimensional hoy.

Capitulo 7.-Flexibilidad, intercambiabilidad y catálogos.

Capitulo 8. - Industrialización, normativa y calidad.

Capítulo 9. - Reflexiones finales.

publicación del

INSTITUTO EDUARDO TORROJA 